\title{
Isolation and characterization of an extremely thermostable D-xylose isomerase from Thermus aquaticus $\mathrm{HB} 8$
}

\author{
ANSElm LeHMACHER $\dagger$ and HANS BisSWANGER* \\ Physiologisch-chemisches Institut der Universität Tübingen, Hoppe-Seyler-Str. 4, D-7400 Tübingen, FRG
}

(Received 3 July 1989; revised 28 November 1989; accepted 4 December 1989)

\begin{abstract}
The extremely thermophilic organism Thermus aquaticus possesses high activities of enzymes catalysing the degradation of xylans and metabolizing $D$-xylose via the pentose phosphate pathway. The $D$-xylose isomerase ( $D$ xylose ketol-isomerase, EC 5.3.1.5), an important enzyme of this process, is efficiently induced by its substrate Dxylose, and, to a lesser extent, by related pentoses and some derivatives of D-xylose. The D-xylose isomerase from T. aquaticus has been purified by anion-exchange chromatography, chromatography on D-xylose agarose and ge! filtration. A single band migrating according to an $M_{\mathrm{r}}$ of 50000 was obtained by SDS-PAGE. An $M_{\mathrm{r}}$ of 196000 for the native enzyme, determined by gel filtration and ultracentrifugation in a glycerol gradient, suggested that the Dxylose isomerase is a homomeric tetramer. Arrhenius plots of the enzyme activity of the D-xylose isomerase were linear up to a temperature of $85^{\circ} \mathrm{C}$. At $70^{\circ} \mathrm{C}$ the enzyme was inactivated in the absence of divalent cations, with a half-life of $4 \mathbb{d}$, while in the presence of $\mathrm{Mn}^{2+}$ or $\mathrm{Co}^{2+}$ it remained fully active for at least 1 month. The enzyme had an isoelectric point at 4.4 and showed a broad optimum in the $\mathrm{pH}$ range from 5.5 to 8.5. No significant differences in the $\mathrm{pH}$ and temperature behaviour could be observed when D-xylose was compared with D-glucose as substrate. Different methods of immobilization of the enzyme to solid supports as well as inclusion into nyion beads were studied. Attachment of the enzyme to epoxy-activated agarose and its co-aggregation with bovine serum albumin gave immobilized preparations with the same stability as free enzyme supplemented with $\mathrm{Mn}^{2+}$ or $\mathrm{Co}^{2+}$.
\end{abstract}

\section{Introduction}

Various micro-organisms are able to grow on hemicelluloses, which amount to $40 \%$ of the plant biomass (Rehm \& Reed, 1982), as sole carbon source. Exoenzymes degrade the polymer to D-xylose, which is transported into the cell, isomerized to D-xylulose and phosphorylated to xylulose 5-phosphate which enters either the pentose phosphate pathway (Doelle, 1975; Barnett, 1976; Dekker \& Richards, 1976; Lam et al., 1980; Kersters-Hilderson et al., 1982; Deleyn et al., 1982; Jeffries, 1983) or the phosphoketolase pathway (Jeffries, 1983). The isomerization of $D$-xylose is carried out by $D$ xylose isomerase (D-xylose ketol-isomerase, EC 5.3.1.5). This enzyme has been used commercially because of its capacity to produce a fructose-enriched syrup by converting D-glucose into fructose (Antrim et al., 1979; Rehm \& Reed, 1982). D-Xylose isomerase is also of industrial interest for the fermentation of

$\dagger$ Present address: Max-Planck-Institut für Biochimie, D-8033 Martinsried, FRG. hemicelluloses to ethanol, together with yeasts (Jeffries, 1983).

The catalytic mechanism of the isomerization reaction is not completely understood. It is not clear whether the enzyme accepts D-glucose solely because of its structural similarity to its physiological substrate $D$-xylose due to a broad specificity of the substrate-binding site or whether D-glucose is isomerized by a different catalytic mechanism (Noltman, 1972). The enzyme has a requirement for divalent metal ions as essential cofactors. $\mathrm{Mn}^{2+}$ or $\mathrm{Mg}^{2+}$ ions are most efficient with $\mathrm{D}$-xylose while the glucose isomerization reaction is more active with $\mathrm{Co}^{2+}$ or $\mathrm{Mg}^{2+}$ ions (Young et al., 1975; Antrim et al., 1979). This observation argues in favour of distinct catalytic mechanisms for the two substrates.

In the work described here we have studied D-xylose isomerase in the extremely thermophilic bacterium Thermus aquaticus. We report the isolation of this enzyme and its characterization, with particular reference to a comparison between the two types of isomerase reactions. The temperature behaviour of the free enzyme is compared with that of the immobilized one. 


\section{Methods}

Growth of the bacteria. Thermus aquaticus HB 8 (ATCC 27634) was obtained fron the Deutsche Sammlung für Mikroorganismen, Braunschweig, FRG. The bacteria were grown in $20 \mathrm{l}$ of the minimal salt medium of Yoshida et al. (1984) with $9.5 \mathrm{~mm}$-ammonium chloride as nitrogen source and $0.5 \% \mathrm{D}$-xylose as carbon source and inducer of the enzyme. Growth was for $14 \mathrm{~h}$ at $70^{\circ} \mathrm{C}$ with $0.2 \mathrm{vol}$. vol. ${ }^{-1} \mathrm{~min}^{-1}$ air and stirring (1000 r.p.m.) in a 201 'Intensor b-20' fermenter (Giovanola Frères). Before each fermentation run the fermenter pot was treated with $25 \%(\mathrm{v} / \mathrm{v})$ nitric acid for $16 \mathrm{~h}$ in order to passivate its steel surface (Sonnleitner et al., 1982). The cells were harvested by centrifugation. From one fermentation run about $90 \mathrm{~g}$ wet weight of cells were obtained. For experiments other than the isolation of D-xylose isomerase, crude extracts were obtained by suspension of the cells in $0.1 \mathrm{M}$-histidine $/ \mathrm{HCl}, \mathrm{pH} 6.0\left[2 \mathrm{ml}(\mathrm{g} \text { cells })^{-1}\right]$, followed by sonication using a type B-12 sonicator (Branson Ultrasonics) for $2 \mathrm{~min}$. The cell debris was removed by centrifugation at $38000 \mathrm{~g}$ for $30 \mathrm{~min}$.

Enzyme assays. (a) D-Xylose isomerase. The formation of D-xylulose from $D$-xylose was measured using the colorimetric assay of Dische \& Borenfreund (1951) in which $20 \mu \mathrm{l}$ of a test mixture, containing $0 \cdot 1 \mathrm{M}$ TES/ $\mathrm{NaOH}$ pH 7.0, 0.2 M-D-xylose and $0.4 \mathrm{~mm}-\mathrm{MnSO}_{4}$, was incubated together with $20 \mu \mathrm{l}$ of the enzyme solution for $10 \mathrm{~min}$ at $70^{\circ} \mathrm{C}$. After this period the samples were put on ice to stop the enzyme reaction and $40 \mu 11.5 \%$ (w/v) cysteine hydrochloride in water, $40 \mu \mathrm{l} 0.12 \%(\mathrm{w} / \mathrm{v})$ carbazole in ethanol, and $1.2 \mathrm{ml} 70 \%(\mathrm{v} / \mathrm{v})$ sulphuric acid were added. After standing for 10 min the absorbance at $540 \mathrm{~nm}$ was determined. The concentration of $\mathrm{D}$-xylulose was determined from a standard curve of D-xylulose. One unit (U) of enzyme activity is equal to the formation of one $\mu \mathrm{mol} \mathrm{D}$-xylulose per min at $70^{\circ} \mathrm{C}$.

(b) D-Glucose isomerase. The test for the $D$-glucose isomerase activity was the same as that for $D$-xylose isomerase, with the exception that the test mixture contained in $20 \mu \mathrm{l} \mathrm{M}$-D-glucose and $0.4 \mathrm{mM}-\mathrm{CoCl}_{2}$ in $0.1 \mathrm{M}-\mathrm{TES} / \mathrm{NaOH}, \mathrm{pH} 7 \cdot 0$. The incubation period for the development of the colour with carbazole was extended to $30 \mathrm{~min}$ and the absorbance was measured at $560 \mathrm{~nm}$. The enzyme activity was calculated on the basis of a standard curve obtained with $D$-fructose.

(c) Other assays. The activity of xylanase was tested using the method of Panbangred et al. (1983a) at $70^{\circ} \mathrm{C}$ following the release of reducing sugars from xylans from oat spelts at $750 \mathrm{~nm}$ by the colorimetric assay of Somogyi (1952). $\beta$-Xylosidase was assayed according to Panbangred et al. (1983b), D-xylose dehydrogenase after Scher \& Horecker (1966) and transketolase according to Brin (1970). Transaldolase was measured by the coupled assay procedure of Brand (1970), and the method of Goldberg et al. (1966) was used to determine the activity of phosphoketolase. The temperature in all these tests was $70^{\circ} \mathrm{C}$. The decrease in the absorbance of $10.5 \mathrm{~mm}$-hydrogen peroxide in $50 \mathrm{~mm}$ potassium phosphate, $\mathrm{pH} 7 \cdot 0$, at $25^{\circ} \mathrm{C}$ was followed spectrophotometrically to determine the activity of catalase (Bergmeyer, 1970).

Protein concentration. Protein concentration was determined according to Bradford (1976). The method of Ahmud \& Saleemuddin (1978) was used to measure the protein content of the immobilized enzyme samples.

Purification of the Dxylose isomerase. Crude extract and DEAE cellulose chromatography. Cells ( $10 \mathrm{~g}$ wet weight) were suspended in $20 \mathrm{ml}$ of $10 \mathrm{~mm}$-histidine $/ \mathrm{HCl}, \mathrm{pH} 6 \cdot 0,0.5 \mathrm{~mm}-\mathrm{PMSF}$ and treated with $10 \mathrm{mg}$ lysozyme at $37^{\circ} \mathrm{C}$ for $45 \mathrm{~min}$. The disintegrated cells were centrifuged for $10 \mathrm{~min}$ at $38000 \mathrm{~g}$ and the resultant supernatant was applied to a $2 \times 8 \mathrm{~cm}$ DEAE-cellulose column and equilibrated with $10 \mathrm{~mm}$-histidine/ $\mathrm{HCl}$, pH 6.0, 0.5 mM-PMSF. The column was washed with the same buffer, which also contained $0.5 \mathrm{mM}-\mathrm{PMSF}, 100 \mathrm{mM}-$ $\mathrm{NaCl}$, at a flow rate of $35 \mathrm{ml} \mathrm{h}^{-1}$. The D-xylose isomerase was eluted with a $60 \mathrm{ml}$ linear gradient of 100 to $500 \mathrm{~mm}-\mathrm{NaCl}$ in $10 \mathrm{~mm}$ histidine $/ \mathrm{HCl}, \mathrm{pH} 6.0,0.5 \mathrm{~mm}-\mathrm{PMSF}$. The active fractions were pooled and dialysed for $14 \mathrm{~h}$ against $10 \mathrm{~mm}$-histidine $/ \mathrm{HCl}, \mathrm{pH} 6.0,0.5 \mathrm{~mm}$ PMSF.

Chromatography on D-xylose/agarose. A column $2 \mathrm{~cm}$ in diameter and $4 \mathrm{~cm}$ in height was filled with D-xylose/agarose, equilibrated with 10 mM-histidine $/ \mathrm{HCl}, \mathrm{pH} 6 \cdot 0,0.5 \mathrm{~mm}-\mathrm{PMSF}$ and run at a flow rate of 20 $\mathrm{ml} \mathrm{h}^{-1}$. The dialysed DEAE-cellulose eluate was applied to the column and washed with $120 \mathrm{ml}$ buffer. To elute the enzyme a $20 \mathrm{ml}$ gradient from 0 to $150 \mathrm{~mm}-\mathrm{NaCl}$ in the same buffer was used. The D-xylose isomerase activity eluted at $50 \mathrm{~mm}-\mathrm{NaCl}$.

Chromatography on Ultrogel Ac A 34. The fractions from the Dxylose/agarose column containing $\mathrm{D}$-xylose isomerase activity were collected and applied to a $2.5 \times 80 \mathrm{~cm}$ Ultrogel Ac A 34 column. Equilibration and elution of this column employed the histidine buffer at a flow rate of $20 \mathrm{ml} \mathrm{h}^{-1}$. The active fractions of the $\mathrm{D}$-xylose isomerase were pooled and concentrated on a $\omega$-aminohexyl-Sepharose $4 \mathrm{~B}$ column to $5 \mathrm{mg} \mathrm{ml}^{-1}$ by the method of Schmincke-Ott \& Bisswanger (1980).

Electrophoresis and isoelectric focusing. The SDS-PAGE (Laemmli, 1970) employed a gradient of 7 to $14 \%(w / v)$ acrylamide and a ratio of acrylamide to $N, N^{\prime}$-methylene-bis-acrylamide of $100: 2 \cdot 68$. Staining of protein bands was done with Coomassie brilliant blue R-250, according to Fairbanks et al. (1971).

Isoelectric focusing was carried out at $4{ }^{\circ} \mathrm{C}$ in a Multiphor unit (Pharmacia) on $125 \times 125 \mathrm{~mm}$ polyacrylamide layers (Servalyt Precotes) at $5 \mathrm{~mA}$, and $1.2 \mathrm{kV}$ for $2 \mathrm{~h}$. The solution for the anode chamber contained $3.3 \mathrm{~g} \mathrm{~L}$-aspartic acid $\mathrm{l}^{-1}$ and $3.7 \mathrm{~g} \mathrm{~L}$-glutamic acid $\mathrm{l}^{-1}$. that for the cathode chamber $20 \mathrm{~g}$ glycine $\mathrm{I}^{-1}$. After focusing, the layer was transferred into $20 \%(\mathrm{w} / \mathrm{v})$ trichloroacetic acid for $15 \mathrm{~min}$, and washed thereafter in methanol/acetic acid/water $(40: 10: 50$, by vol.) for $30 \mathrm{~s}$. Staining was done for $1 \mathrm{~h}$ with $0.08 \%$ Coomassie brilliant blue $\mathrm{G}-250$ and destaining with the methanol/acetic acid/water mixture. The layer was dried at $100{ }^{\circ} \mathrm{C}$ for $5 \mathrm{~min}$.

Immobilization of D-xylose isomerase. (a) Hollow-fibre entrapment. The method of Chambers et al. (1976) was used to immobilize $2 \mathrm{mg}$ purified D-xylose isomerase $\mathrm{ml}^{-1}$ in $10 \mathrm{mM}$-histidine $/ \mathrm{HCl}, \mathrm{pH} \mathrm{6.0,} \mathrm{to} 50000 \mathrm{M}_{\mathrm{r}}$ cut-off fibres of the hollow-fibre cartridge BPR 500006 (Berghof).

(b) Inclusion into nylon beads. Using the method of Chang (1976), $1 \mathrm{ml}$ $10 \mathrm{~mm}$-histidine $/ \mathrm{HCl}, \mathrm{pH} 6 \cdot 0$, containing $2 \mathrm{mg}$ of purified $\mathrm{D}$-xylose isomerase was mixed with the same volume of a solution of $44 \mathrm{mg} \mathrm{1,6-}$ diaminohexane, $16 \mathrm{mg}$ sodium hydrogen carbonate and $66 \mathrm{mg}$ sodium carbonate in water. To this mixture a freshly prepared solution of 18 $\mathrm{mm}$-sebacoyl chloride $(0.4 \mathrm{ml}$ sebacoyl chloride in $20 \mathrm{ml}$ chloroform and $80 \mathrm{ml}$ cyclohexane) was added drop-wise with a microlitre syringe so that the beads were formed without touching one another. After 5 min the organic phase was decanted and the solute was allowed to evaporate completely. The beads were then washed with $0.9 \%$ sodium chloride in $50 \mathrm{~mm}$-potassium phosphate, $\mathrm{pH} 7 \cdot 0$.

(c) Fixation on cyanogen-bromide-activated Sepharose 4B. D-Xylose isomerase was immobilized on cyanogen-bromide-activated Sepharose 4B according to Cuatrecasas et al. (1968). Gel $(1 \mathrm{~g})$ was washed with $200 \mathrm{ml} 1 \mathrm{~mm}-\mathrm{HCl}$ and suspended in $1 \mathrm{ml} 0 \cdot 1 \mathrm{M}$-sodium bicarhonate, $\mathrm{pH}$ 8.3 , that contained $0.5 \mathrm{M}$-sodium chloride and $2 \mathrm{mg}$ of the purified enzyme. The suspension was shaken at room temperature for $5 \mathrm{~h}$. The supernatant was discarded, $20 \mathrm{ml}$ of $0.2 \mathrm{M}$-glycine $/ \mathrm{NaOH}$, pH 8.0 were added, and the mixture was shaken for another $2 \mathrm{~h}$ in order to block free cyanogen bromide groups.

(d) Immobilization on epoxy-activated agarose. Epoxy-activated agarose $(1 \mathrm{~g})$ was washed with $100 \mathrm{ml}$ distilled water and allowed to react with $1 \mathrm{ml}$ of a solution of $2 \mathrm{mg}$ purified D-xylose isomerase in $0.1 \mathrm{M}$ - 
sodium bicarbonate, $0.5 \mathrm{M}$-sodium chloride, $\mathrm{pH} 8.5$, at room temperature for $5 \mathrm{~h}$ with constant shaking. Unreacted epoxy groups were inactivated by shaking for $2 \mathrm{~h}$ in $0 \cdot 2 \mathrm{M}$-glycine/ $\mathrm{NaOH}, \mathrm{pH} 8 \cdot 0$.

(e) Co-immobilization with bovine serum albumin $(B S A)$ and glutaraldehyde. D-Xylose isomerase and BSA were co-immobilized according to the method of Broun (1976). Purified D-xylose isomerase ( $2 \mathrm{mg}), 60 \mathrm{mg}$ BSA and $2 \mathrm{mg}$ glutaraldehyde in $1 \mathrm{ml} 50 \mathrm{~mm}$-potassium phosphate, $\mathrm{pH}$ $7 \cdot 0$, were frozen at $-30^{\circ} \mathrm{C}$ and allowed to thaw slowly in a refrigerator at $4{ }^{\circ} \mathrm{C}$ for $4 \mathrm{~h}$. The co-polymer was washed successively with $20 \mathrm{ml}$ volumes of distilled water, with $0.1 \mathrm{M}$-L-lysine, and finally with $50 \mathrm{~mm}$ potassium phosphate, $\mathrm{pH} 7 \cdot 0$.

Chemicals. Yeast extract and Bacto-Tryptone were purchased from Difco; catalase from bovine liver, BSA and phenylmethylsulphonyl fluoride (PMSF) were obtained from Boehringer Mannheim; D-xylose and sebacoyl chloride were from Fluka AG; DEAE-cellulose (DE-52) was from Whatman; D-xylitol, lysozyme from chicken egg white, acrylamide, Coomassie brilliant blue R-250 and G-250, Servalyte Precotes, $N, N^{\prime}$-methylene-bis-acrylamide, $N, N, N^{\prime}, N^{\prime}$-tetramethylethylenediamine and SDS were from Serva; D-glucose, D-arabinose, Dfructose, D-galactose, D-lyxose, D-ribose, D-xylose 1-phosphate, Dxylulose, methyl $\alpha$-D-xyloside, methyl $\beta$-D-xyloside, 2- $O$-methyl-Dxylose, D-xylose tetraacetate, xylan from oat spelts, $\omega$-aminohexylSepharose 4B, cyanogen-bromide-activated Sepharose 4B, epoxyactivated agarose [1,4-bis-(2,3-epoxypropoxyl)-butane attached to cross-linked agarose], TES, Tris, $M_{\mathrm{r}}$ markers MW-SDS-200 and isoelectric focusing markers IEF-MI were from Sigma; Ultrogel Ac A 34 was from LKB; carbazole was from Aldrich. All other chemicals were obtained from Merck.

D-Xylose-agarose was synthesized from epoxy-activated agarose according to Sundberg \& Porath (1974). D-Xylonate was prepared according to Moore \& Link (1940). D-Xylose 5-phosphate was produced by the method of Levene \& Raymond (1933).

\section{Results}

\section{$D$ Xylose metabolism of $T$. aquaticus $H B 8$}

High- $M_{\mathrm{r}}$ xylans are the main source of $\mathrm{D}$-xylose. Therefore it should be advantageous to any microorganism able to metabolize D-xylose to also possess xylanase activity. Accordingly, T. aquaticus was grown at $70{ }^{\circ} \mathrm{C}$ in minimal medium with $0.5 \% \mathrm{D}$-xylose as carbon source. After $20 \mathrm{~h}$ the cells were collected by centrifugation and disrupted by sonication. The crude cell-extract and the culture filtrate were tested for xylanase activity. High levels of activity $\left(986 \mathrm{U} \mathrm{l}^{-1}\right)$ were found in the culture filtrate, while no xylanase activity could be detected in the crude extract. However, activities of Dxylose isomerase $\left(25 \mathrm{U}^{-1}\right)$ and $\mathrm{D}$-xylulokinase (3.8 $\mathrm{U} \mathrm{l}^{-1}$ ) (which feeds $\mathrm{D}$-xylose into the pentose phosphate pathway) as well as transketolase $\left(71 \mathrm{U} \mathrm{l}^{-1}\right)$ and transaldolase $\left(13 \mathrm{U}^{-1}\right)$ (which catalyse important reactions of this pathway) were found in this fraction. Enzyme activities for alternative pathways such as Dxylose dehydrogenase, or phosphoketolase, were not detected in the crude extract of the cells of $T$. aquaticus, nor was $\beta$-xylosidase activity detected.

\section{Table 1. Induction of synthesis of $D$-xylose isomerase}

The cells were cultivated in minimal medium with $0.5 \%$ glycerol as carbon source. After reaching an optical density of 0.8 the cells were collected by centrifugation, washed with a sterile solution of $0.9 \%$ sodium chloride in $50 \mathrm{~mm}$-potassium phosphate, $\mathrm{pH} 7.0$, and resuspended in $10 \mathrm{~mm}$-potassium phosphate, $\mathrm{pH} 7.0$, containing $0.5 \mathrm{~mm}$ of the inducer. The suspension was shaken for $20 \mathrm{~min}$ at $70^{\circ} \mathrm{C}$, centrifuged and the cells disrupted by sonication. After further centrifugation for $10 \mathrm{~min}$ at $38000 \mathrm{~g}$ the activity of the D-xylose isomerase and the protein content were measured in the crude extract. The purity of the compounds was checked by thin-layer chromatography.

\begin{tabular}{lc}
\hline \hline \multicolumn{1}{c}{ Inducer } & $\begin{array}{c}\text { Specific activity } \\
{\left[U(\mathrm{mg} \text { protein })^{-1}\right]}\end{array}$ \\
\hline D-Xylose & $0 \cdot 109$ \\
D-Xylonate & $0 \cdot 104$ \\
D-Xylitol & $0 \cdot 080$ \\
Methyl $\alpha$-D-xyloside & $0 \cdot 045$ \\
Methyl $\beta$-D-xyloside & $0 \cdot 041$ \\
2-O-Methyl-D-xylose & 0.056 \\
D-Xylosetetraacetate & $0 \cdot 009$ \\
D-Xylose 1-phosphate & $0 \cdot 009$ \\
D-Xylose 5-phosphate & $0 \cdot 010$ \\
D-Lyxose & $0 \cdot 063$ \\
D-Ribose & $0 \cdot 022$ \\
D-Arabinose & $0 \cdot 008$ \\
D-Glucose & 0.008 \\
D-Galactose & $0 \cdot 007$ \\
D-Fructose & $0 \cdot 010$ \\
Glycerol & $0 \cdot 009$ \\
\hline \hline
\end{tabular}

\section{Induction of the D-xylose isomerase activity}

In many organisms it has been shown that D-xylose isomerase is induced by its substrate D-xylose (Shamanna \& Sanderson, 1979; Briggs et al., 1984; Lawlis et al., 1984; Wilhelm \& Hollenberg, 1985; Marcel et al., 1987). Induction of the enzyme by a range of compounds was tested in $T$. aquaticus. The specific activities obtained are shown in Table 1. D-Xylose was the most potent inducer of the D-xylose isomerase. Compounds structurally related to D-xylose, like $\mathrm{D}$-xylonate, $\mathrm{D}$-xylitol, 2-Omethyl-D-xylose, methyl $\alpha$-D-xyloside and methyl $\beta$-Dxyloside were also able to stimulate the synthesis of the enzyme. All hexoses tested were ineffective, while, of the pentoses, D-ribose was a weak and D-lyxose a fairly good inducer. The metal ions $\mathrm{Mg}^{2+}, \mathrm{Mn}^{2+}$ and $\mathrm{Co}^{2+}$, which are essential cofactors of the enzyme (Antrim et al., 1979), were ineffective as inducers.

The rate of induction of $D$-xylose isomerase activity by D-xylose is shown in Fig 1 (a). A steep increase in the Dxylose isomerase activity was observed for $20 \mathrm{~min}$, followed by a decline to reach a constant level of about half of the maximum activity after $1 \mathrm{~h}$. In Fig. $1(b)$ the dependence of the induction on the concentration of $\mathrm{D}$ xylose is presented. The D-xylose isomerase activity, measured after an induction period of $20 \mathrm{~min}$, was 


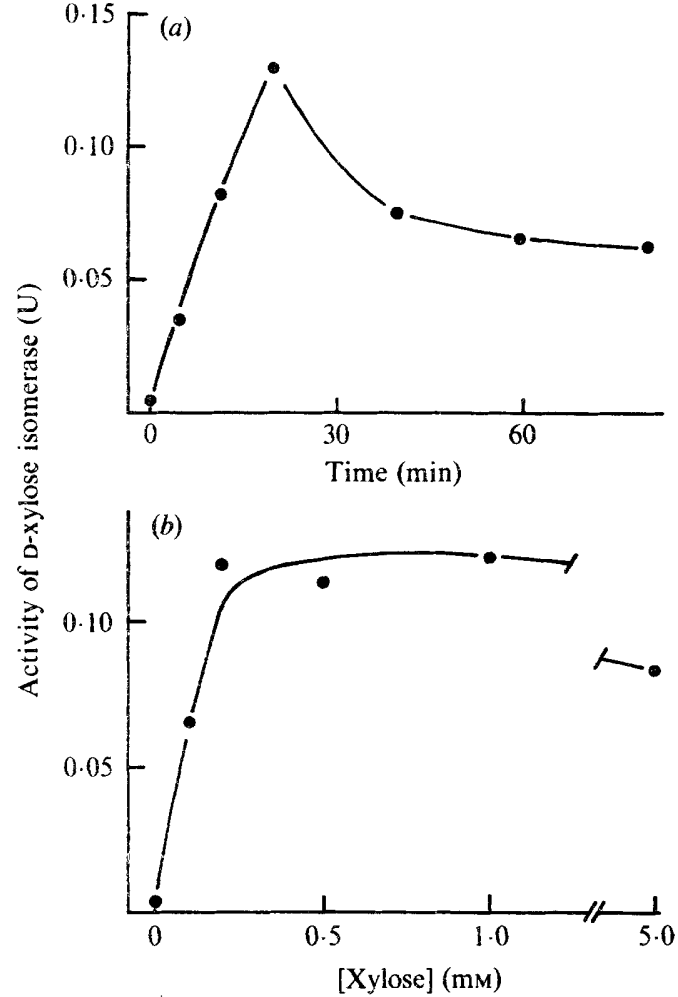

Fig. 1. Induction of D-xylose isomerase activity. T. aquaticus cultures were prepared as described in Table 1 and the rate of induction of the enzyme by D-xylose measured (a). The extent of induction was also assayed after incubation of washed cell suspension for $20 \mathrm{~min}$ in the presence of different concentrations of D-xylose $(b)$.

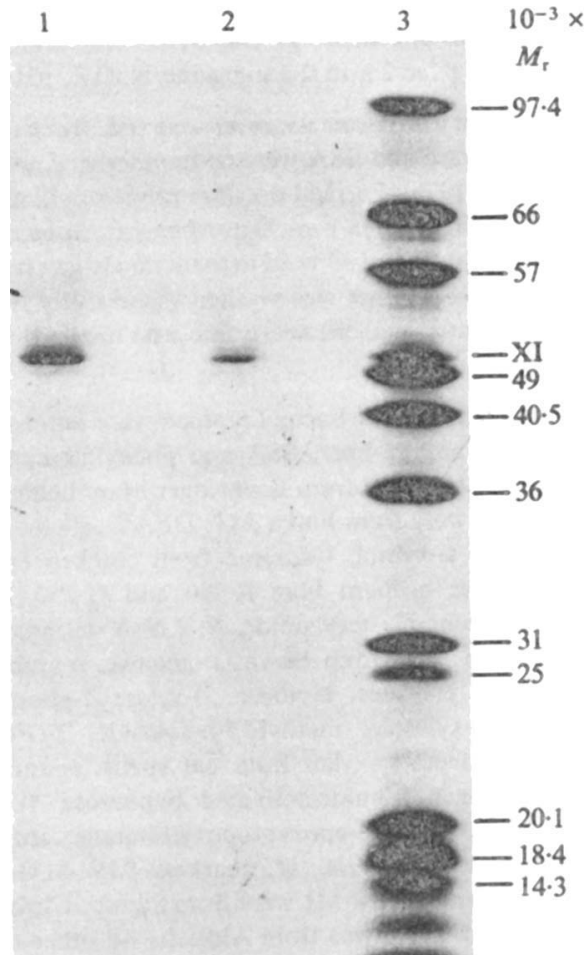

Fig. 2. SDS-PAGE of purified D-xylose isomerase from T. aquaticus. Lanes 1 and 2 contain $4 \mu \mathrm{g}$ and $2 \mu \mathrm{g} \mathrm{D}$-xylose isomerase, respectively. Lane 3 contains $M_{\mathrm{r}}$ marker proteins ( $4 \mu \mathrm{g}$ each) added to $3 \mu \mathrm{g}$ D-xylose isomerase. $M_{\mathrm{r}}$ marker proteins were: phosphorylase $b(97400)$, BSA $(6600)$, pyruvate kinase $(57000)$, fumarase $(49000)$, creatine kinase (40 500), glyceraldehyde-3-phosphate dehydrogenase (36000), carbonic anhydrase $(31000)$, chymotrypsinogen A (25000), trypsin inhibitor (20100), $\beta$-lactoglobulin (18400), lysozyme (14300). XI marks position of $\mathrm{D}$-xylose isomerase.

Table 2. Purification of D-xylose isomerase

All fractions were assayed for both D-xylose isomerase (XI) and D-glucose isomerase (GI) activities.

\begin{tabular}{|c|c|c|c|c|c|c|c|c|c|c|}
\hline \multirow[b]{2}{*}{ Purification step } & \multirow{2}{*}{$\begin{array}{c}\text { Volume } \\
\text { (ml) }\end{array}$} & \multirow{2}{*}{$\begin{array}{c}\text { Protein } \\
\left(\mathrm{mg} \mathrm{ml}^{-1}\right)\end{array}$} & \multicolumn{2}{|c|}{$\begin{array}{l}\text { Total } \\
\text { activity } \\
\text { (U) }\end{array}$} & \multicolumn{2}{|c|}{$\begin{array}{l}\text { Specific } \\
\text { activity } \\
\left(\mathrm{U} \mathrm{mg^{-1 } )}\right.\end{array}$} & \multicolumn{2}{|c|}{$\begin{array}{c}\text { Yield } \\
(\%)\end{array}$} & \multicolumn{2}{|c|}{$\begin{array}{l}\text { Purification } \\
\text { factor }\end{array}$} \\
\hline & & & $\mathbf{X I}$ & GI & XI & GI & XI & GI & $\mathbf{X I}$ & GI \\
\hline Crude extract & 10 & 6.9 & $34 \cdot 1$ & $20 \cdot 2$ & 0.5 & 0.3 & 100 & 100 & 1 & 1 \\
\hline DEAE-Cellulose & $23 \cdot 5$ & $1 \cdot 4$ & $36 \cdot 2$ & $21 \cdot 0$ & $1 \cdot 1$ & 0.66 & 106 & 104 & $2 \cdot 2$ & $2 \cdot 3$ \\
\hline D-Xylose/agarose & 10 & 1.9 & $34 \cdot 9$ & $20 \cdot 0$ & 1.9 & $1 \cdot 1$ & 102 & 99 & $3 \cdot 8$ & 3.7 \\
\hline Ultrogel Ac A 34 & 31 & 0.1 & $35 \cdot 4$ & $20 \cdot 2$ & $11 \cdot 4$ & 6.5 & 104 & 100 & $22 \cdot 8$ & $21 \cdot 7$ \\
\hline
\end{tabular}

greatest with $0 \cdot 2-1 \mathrm{mM}-\mathrm{D}-\mathrm{xylose}$. Above $1 \mathrm{~mm}$-D-xylose the activity declined slightly.

\section{Purification of the D-xylose isomerase from T. aquaticus $H B 8$}

The purification of D-xylose isomerase is summarized in Table 2. Three chromatographic steps, anion-exchange chromatography on DEAE-cellulose, chromatography with D-xylose/agarose and gel filtration on Ultrogel Ac A 34 , resulted in a highly purified preparation of high yield. D-Glucose isomerase activity co-purified exactly with the D-xylose isomerase activity. One predominant protein band was found in the SDS-PAGE (Fig. 2). From the data an apparent $M_{\mathrm{r}}$ of 50000 was determined for the enzyme band. Isoelectric focusing of the purified D- 
xylose isomerase gave a single protein band corresponding to an isoelectric point of 4.4 (not shown).

The $M_{\mathrm{r}}$ of the native $\mathrm{D}$-xylose isomerase from $T$. aquaticus was determined by gel filtration. The purified enzyme was passed through a Sephacryl S-300 column together with standard proteins of known $M_{\mathrm{r}}$; an $M_{\mathrm{r}}$ of 191000 was determined.

The $M_{\mathrm{r}}$ of native $\mathrm{D}$-xylose isomerase was also determined by the technique of gradient ultracentrifugation according to Martin \& Ames (1961). In order to avoid interactions of sugar with the enzyme, glycerol was used instead of sucrose to form a linear gradient from 10 to $50 \%(\mathrm{v} / \mathrm{v})$. The $\mathrm{D}$-xylose isomerase was centrifuged in the gradient together with malate dehydrogenase and catalase as standards of known $M_{\mathrm{r}}$. An estimate of the $M_{\mathrm{r}}$ of the D-xylose isomerase of 196000 was obtained based on the assumption that the ratio of the distances travelled by standard (s) and sample (x) enzymes in the gradient corresponds to the ratio of their respective sedimentation coefficients, $s_{20, \mathrm{w}(\mathrm{s})} / s_{20, \mathrm{w}(\mathrm{x})}$ (Martin \& Ames, 1961).

\section{Effects of temperature on D-xylose isomerase}

The enzymic activity of $D$-xylose isomerase was measured at various temperatures utilizing $D$-xylose and D-glucose, respectively, as substrates. For both substrates the Arrhenius plots yielded straight lines up to a temperature of $85^{\circ} \mathrm{C}$ and declined thereafter, probably because of thermal inactivation (not shown). From the slopes of the linear part of these plots activation energies of $64.8 \mathrm{~kJ} \mathrm{~mol}^{-1}$ and of $98.3 \mathrm{~kJ} \mathrm{~mol}^{-1}$ were calculated for D-xylose and for D-glucose, respectively.

To test its stability with respect to temperature the Dxylose isomerase was incubated at $4{ }^{\circ} \mathrm{C}, 25^{\circ} \mathrm{C}$ and $70^{\circ} \mathrm{C}$. After different intervals samples were taken to determine the D-xylose isomerase activity (Fig. 3). The enzyme was stable at $4{ }^{\circ} \mathrm{C}$ and $25^{\circ} \mathrm{C}$ for more than 1 month, while at $70^{\circ} \mathrm{C}$ its activity declined with a half-life of $4 \mathrm{~d}$. Since the D-xylose isomerase requires divalent cations for its catalytic activity (Antrim et al., 1979), the stability of the enzyme at $70^{\circ} \mathrm{C}$ was tested in the absence and presence of $\mathrm{Mg}^{2+}, \mathrm{Mn}^{2+}$ and $\mathrm{Co}^{2+} . \mathrm{Mn}^{2+}$ and $\mathrm{Co}^{2+}$ individually protected the enzyme from thermal inactivation for at least 1 month, while stabilization was not observed with $\mathrm{Mg}^{2+}$ (Fig. 3).

\section{Effects of pH on D-xylose isomerase}

The activity of the D-xylose isomerase increased between $\mathrm{pH} 3$ and 5 , remained nearly constant in the $\mathrm{pH}$ range from 5.5 to 8.5 , and declined at $\mathrm{pH} 10$ (Fig. $4 a$ ). The glucose isomerase reaction showed nearly the same dependence on $\mathrm{pH}$, though the flanks of the curve were less steep. This $\mathrm{pH}$ profile indicates more than one

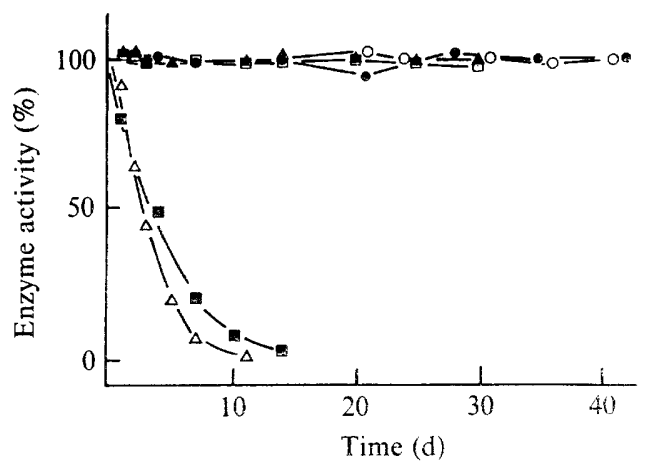

Fig. 3. Thermal stability of the D-xylose isomerase. The purified enzyme was incubated at a concentration of $2 \mathrm{mg} \mathrm{ml}^{-1}$ in $50 \mathrm{~mm}$ TES/ $/ \mathrm{NaOH}, \mathrm{pH} 7.0$, at $4{ }^{\circ} \mathrm{C}(\bullet), 25^{\circ} \mathrm{C}(\mathrm{O})$, and at $70^{\circ} \mathrm{C}$ in the absence $(\square)$ and in the presence of $0.5 \mathrm{~mm}$-magnesium chloride $(\triangle), 0.5 \mathrm{~mm}$ manganese chloride $(\Delta)$ and $0.5 \mathrm{mM}$-cobalt chloride $(\square)$.

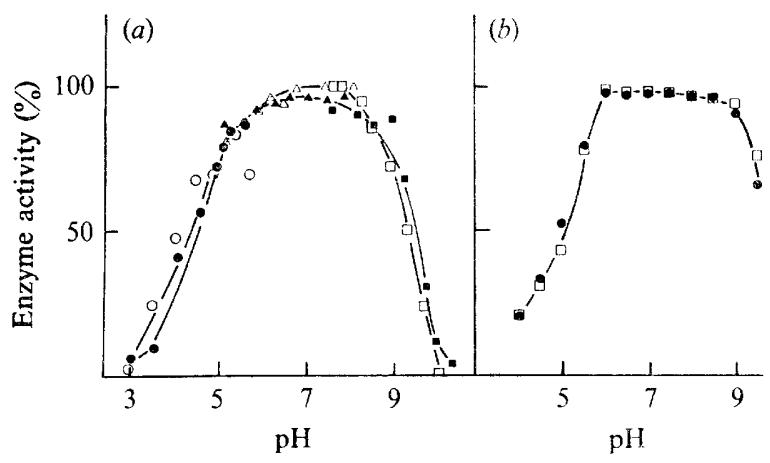

Fig. 4. Dependence of the enzyme activity and stability of D-xylose isomerase on the $\mathrm{pH}$ value. (a) The D-xylose isomerase reaction $(\bullet, \Delta, \square)$ was tested with $4 \mu \mathrm{g}$ and the D-glucose isomerase reaction $(O, \Delta, \square)$ with $2 \mu \mathrm{g}$ of the purified $D$-xylose isomerase in buffer systems of different $\mathrm{pH}$ values: $\mathrm{pH} 2 \cdot 9-5 \cdot 65,50 \mathrm{mM}$-acetic acid/sodium acetate $(\bullet, 0)$; pH 5.1-8.0, $50 \mathrm{mM}-\mathrm{TES} / \mathrm{NaOH}(\Delta, \Delta)$; pH 7.55-10.0, $50 \mathrm{~mm}-$ glycine/ $\mathrm{NaOH}(\boldsymbol{\square}, \square)$. For the $\mathbf{D}$-glucose isomerase reaction the ordinate scale must be multiplied by a factor of $0 \cdot 2$. (b) Samples of purified D-xylose isomerase $\left(2 \mathrm{mg} \mathrm{ml}^{-1}\right)$ were preincubated for $1 \mathrm{~h}$ at $25^{\circ} \mathrm{C}$ in the above-mentioned buffer system at the respective $\mathrm{pH}$ value given at the abscissa. After this time the activities of $\mathrm{D}$-xylose isomerase $(\square)$ and D-glucose isomerase (๑) were tested under normal test conditions at $\mathrm{pH} 7 \cdot 0$. The respective activities of the untreated enzyme are defined as $100 \%$. The buffer systems are the same as those described for $(a)$.

functional group involved in the $\mathrm{pH}$-dependent mechanism.

The stability of the D-xylose isomerase as a function of $\mathrm{pH}$ was tested by preincubation of the enzyme at $25^{\circ} \mathrm{C}$ at different $\mathrm{pH}$ values for $1 \mathrm{~h}$. After the incubation the activities of D-xylose isomerase and D-glucose isomerase were measured at $\mathrm{pH} \mathrm{7.0.} \mathrm{The} \mathrm{stability} \mathrm{curves} \mathrm{obtained}$ by this experiment (Fig. $4 b$ ) resembled the $\mathrm{pH}$ optimum curves (Fig. $4 a$ ) and no difference was observed with Dxylose or with D-glucose as substrate. 
Table 3. Immobilization of the D-xylose isomerase from T. aquaticus

\begin{tabular}{lccc}
\hline \hline & \multicolumn{3}{c}{ Xylose isomerase activity } \\
\cline { 2 - 4 } Immobilization & $\begin{array}{c}\text { Yield } \\
(\%)\end{array}$ & $\begin{array}{c}\text { Sp. act. } \\
\left(\mathrm{U} \mathrm{mg}^{-1}\right)\end{array}$ & $\begin{array}{c}\text { Ratio } \\
\text { Sp. act.immobilized } \\
\text { Sp. act.native }\end{array}$ \\
\hline technique & 100 & 5.43 & 1.0 \\
Hollow fibre & 56 & 2.93 & 0.54 \\
Nylon beads & 71 & 4.58 & 0.84 \\
$\quad \begin{array}{l}\text { Epoxy-activated } \\
\text { agarose }\end{array}$ & 65 & 5.03 & 0.92 \\
$\quad \begin{array}{l}\text { Cyanogen bromide- } \\
\text { Glutaraldehyde/BSA }\end{array}$ & 37 & ND & ND \\
\hline \hline
\end{tabular}

ND, Not determined

\section{Immobilization of the D-xylose isomerase}

Different techniques of immobilization of the purified Dxylose isomerase from $T$. aquaticus were tested. These included fixation on solid supports by epoxy- and cyanogen-bromide-activated agarose, inclusion into nylon beads and hollow fibres and co-aggregation with BSA by cross-linking with glutaraldehyde (Table 3 ). The best results were obtained with hollow-fibre entrapment, which was done without loss of enzyme activity. About two-thirds of the activity was retained after fixation of the enzyme on agarose. All five immobilized enzyme preparations remained completely active for at least $45 \mathrm{~d}$ when stored at $4{ }^{\circ} \mathrm{C}$ or at $25^{\circ} \mathrm{C}$. The activity disappeared, however, with a half-life of about $4 \mathrm{~d}$, upon incubation at $70{ }^{\circ} \mathrm{C}$, with the exception of the enzyme attached to epoxy-activated agarose and that co-aggregated with BSA (Fig. 5).

\section{Discussion}

The D-xylose isomerases from Salmonella typhimurium (Shamanna \& Sanderson, 1979), Escherichia coli (Briggs et al., 1984; Lawlis et al.,1984), Bacillus subtilis (Wilhelm \& Hollenberg, 1985) and Streptomyces violaceoniger (Marcel et al., 1987) are under positive genetic control. DXylose binds to a regulator protein, which activates the promoter of the D-xylose operon. A similar mechanism may occur in $T$. aquaticus, where the enzyme is induced 14 -fold by $\mathrm{D}$-xylose. Analogues of $\mathrm{D}$-xylose, methyl $\alpha$-Dxyloside and methyl $\beta$-D-xyloside, 2- $O$-methyl-D-xylose, $\mathrm{D}$-lyxose, D-xylonate and $\mathrm{D}$-xylitol, induce the enzyme substantially while other sugars are ineffective.

Since the $\mathrm{D}$-xylose isomerase from $T$. aquaticus becomes liberated after sonication or incubation of the

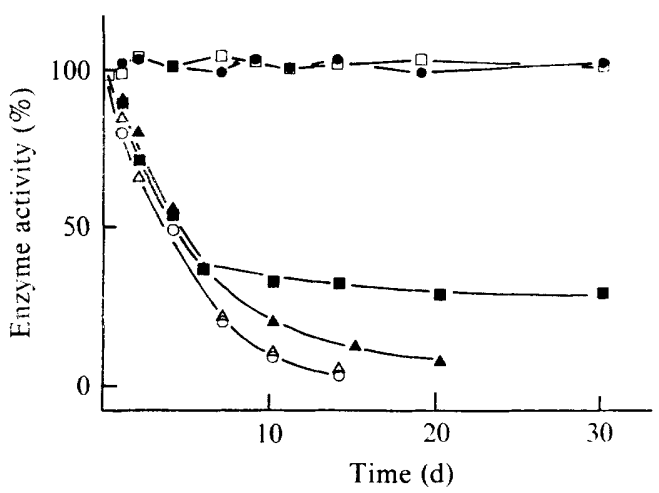

Fig. 5. Thermal stability of immobilized D-xylose isomerase. The immobilized enzyme preparations were incubated in $50 \mathrm{~mm}$-TES buffer at $70^{\circ} \mathrm{C}$, and samples corresponding to $2 \mathrm{mg} \mathrm{ml}^{-1}$ were taken at different times and the D-glucose isomerase activity was tested. The activity of the native enzyme $(O)$ was defined as $100 \%$ at $t=0 ; \triangle$, hollow fibre entrapment; $\mathbf{m}$, inclusion into nylon beads: $\bullet$, epoxyactivated agarose; $\boldsymbol{\Delta}$, cyanogen bromide-activated agarose: $\square$, coimmobilization with BSA by glutaraldehyde cross-linking.

cells with lysozyme, it is apparently cytosolic. No enzyme activity is released after osmotic shock treatment (not shown), as would be expected for an enzyme located in the periplasm.

The enzyme appears to be relatively stable against denaturation and, therefore, high yields could be obtained during the purification procedure. As D-xylose isomerase eluted from xylose/agarose in the presence of salt, but was not displaced by D-xylose (data not shown), this column was apparently acting as an ion-exchanger rather than as a true affinity ligand for this enzyme. The co-purification of both D-xylose and D-glucose isomerase activities strongly suggested that these are activities of the same enzyme molecule. No evidence was found for the existence of separate enzyme molecules for the two activities in $T$. aquaticus.

An $M_{\mathrm{r}}$ of about 196000 for the native D-xylose isomerase from T. aquaticus and of 50000 for its subunits suggests that the enzyme is a homomeric tetramer. These results are consistent with X-ray crystallography data from Streptomyces rubiginosus and Arthrobacter (Carrell et al., 1984; Henrick et al., 1987) and also with the $M_{\mathrm{r}}$ determinations of the enzyme from Streptomyces griseofuscus (Kasumi et al., 1981), Streptomyces violaceoruber (Callens et al., 1985), Bacillus coagulans (Danno, 1970), Lactobacillus brevis and Lactobacillus xylosus (Yamanaka \& Takahara, 1977), where values around 180000 for the native enzyme and 43000 for the identical subunits were reported. In contrast to these results, the D-xylose isomerases from Streptomyces olivochromogenes (Suekane et al., 1978) appear to be homomeric dimers of subunits 
with an $M_{\mathrm{r}}$ of $2 \times 56000$ and $2 \times 40000$, respectively, while the enzyme from Bacillus stearothermophilus was described as a monomer (Suekane et al., 1978) with an $M_{\mathrm{r}}$ of 127000 .

The D-xylose isomerase from $T$. aquaticus has a broad pH optimum sharply declining on both sides, giving halfmaximal $\mathrm{pH}$ values of $4 \cdot 5$ and $9 \cdot 4$. D-Xylose isomerase from Streptomyces has a less broad optimum with halfmaximal values of 6.8 and 8.4 . For this enzyme as well as for the enzyme from Lactobacillus an esential histidine residue was found (Gaikwad et al., 1988; Vangrysperre $e t$ al., 1988). In addition these enzymes contain an activesite carboxylate residue (Vangrysperre et al., 1989). Recently it was reported that conserved histidine at position 219 and glutamic acid at position 180 appear to be involved in the binding of a divalent metal ion in the enzyme from Streptomyces albus (Dauter et al., 1989). DXylose isomerase has significant similarity to the triosephosphate isomerase which is also an aldose-ketose isomerase. In the latter enzyme the nucleophilic glutamic acid 165 , electrophilic lysine 13 , and histidine 95 bind to the substrate (Straus et al., 1985; Raines \& Knowles, 1986). The half-maximal $\mathrm{pH}$ values of the $\mathrm{D}$-xylose isomerase from $T$. aquaticus suggest that a similar situation may exist for the catalytic mechanism of this enzyme.

$\mathrm{D}$-Xylose isomerase from $T$. aquaticus proved to be very stable. It loses no activity for at least 1 month when stored at $4{ }^{\circ} \mathrm{C}$ as well as at $25^{\circ} \mathrm{C}$, irrespective of the presence of cofactors, and even at $70^{\circ} \mathrm{C}$ a half-life of $4 \mathrm{~d}$ is remarkable. $\mathrm{Mn}^{2+}$ and $\mathrm{Co}^{2+}$ ions, which act as cofactors of the enzyme, cause a dramatic enhancement of the enzyme stability.

The high stability of the D-xylose isomerase is further illustrated by the fact that the enzyme could be immobilized by different techniques without severe losses of enzyme activity. In the absence of divalent cations the immobilized enzyme was more stable than the native one.

We thank Dr Dennis Grogan for the help in the preparation of the manuscript. A.L. thanks the Friedrich-Ebert-Stiftung, Bonn, for a grant.

\section{References}

Ahmud, H. \& Saleemuddin, M. (1978). A Coomassie blue-binding assay for the microquantitation of immobilized proteins. Analytical Biochemistry 148, 533-541.

Antrim, R. L., Colilla, W. \& Schnyder, B. J. (1979). Glucose isomerase production of high fructose syrup. Applied Biochemistry and Bioengineering 2, 97-155.

BARNETT, J. A. (1976). The utilization of sugars by yeasts. Advances in Carbohydrate Chemistry and Biochemistry 32, 125-234.

BergmeYer, H. U. (1970). Katalase. In Methoden der Enzymatischen Analyse, vol. 1, pp. 439-440. Edited by H. U. Bergmeyer. Weinheim: Verlag Chemie.
BRADFORD, M. M. (1976). A rapid and sensitive method for the quantitation of microgram quantities of protein using the principle of protein-dye binding. Analytical Biochemistry 72, 248-254.

BRAND, K. (1970). Transaldolase. In Methoden der Enzvmatischen Analyse, vol. 1, pp. 674-678. Edited by H. U. Bergmeyer. Weinheim: Verlag Chemie.

Briggs, K. A., LanCashire, W. E. \& Harley, B. S. (1984). Molecular cloning, DNA structure and expression of the Escherichia coli Dxylose isomerase. EMBO Journal 3, 611-616.

BRIN, M. (1970). Transketolase. In Methoden der Enzymatischen Analyse, vol. 1, pp. 666-673. Edited by H. U. Bergmeyer. Weinheim: Verlag Chemie.

Broun, G. B. (1976). Chemical aggregated enzymes. Methods in Enzymology 44, 263-280.

Callens, M., Kersters-Hilderson, H., Vandekerckhove, J., van Opstal, O. \& De Bruyne, C. K. (1985). Purification and some physicochemical properties of D-xylose isomerase from Streptomyces violaceoruber. Biochemistry International 11, 467-475.

Carrell, H. L., Rubin, B. H., Hurley, T. J. \& Glusker, J. B. (1984). $\mathrm{X}$-ray crystal structure of $\mathrm{D}$-xylose isomerase at $4-\AA$ resolution. Journal of Biological Chemistry 259, 3230-3236.

Chambers, R. P., Cohen, W. \& Baricos, W. H. (1976). Physical immobilization of enzymes by hollow-fiber membranes. Methods in Enzymology 44, 291-317.

ChANG, T. M. S. (1976). Microencapsulation of enzymes and biologicals. Methods in Enzymology 44, 201-218.

Cuatrecasas, P., WilcheK, M. \& Anfinsen, C. B. (1968). Selective enzyme purification by affinity chromatography. Proceedings of the National Academy of Sciences of the United States of America 61, 636643 .

DanNo, G. (1970). Studies of a D-glucose isomerizing enzyme from Bacillus coagulans. Agricultural and Biological Chemistry 34, 17951804.

Dauter, Z., Dauter, M., Hemker, J., Witzel, H. \& Wilson, K. S. (1989). Crystallisation and preliminary analysis of glucose isomerase from Streptomyces albus. FEBS Letters 247, 1-8.

DekKeR, R. F. H. \& Richards, G. N. (1976). Hemicellulases, their occurrence, purification, properties, and mode of action. Advances in Carbohydrate Chemistry and Biochemistry 32, 317-352.

Deleyn, F., Claeyssens, M. \& De Bruyne, C. (1982). $\beta$-D-Xylosidase from Penicillium wortmanni. Methods in Enzymology 83, 639-644.

DisCHE, Z. \& BORENFREUND, E. (1951). A new spectrophotometric method for the detection and determination of ketosugars and trioses. Journal of Biological Chemistry 192, 583-587.

DoElle, H. W. (1975). Phosphoketolase pathway. In Bacterial Metabolism, 2nd edn, pp. 244-250. New York: Academic Press.

Fairbanks, G., Steck, T. L. \& Wallach, T. F. H. (1971). Electrophoretic analysis of the major polypeptides of the human erythrocyte membrane. Biochemistry 10, 2606-2617.

Gaikwad, S. M., More, M. W., Vartak, H. G. \& Deshpande, V. V. (1988). Evidence for the essential histidine residue at the active site of glucose/xylose isomerase from Streptomyces. Biochemical and Biophysical Research Communications 155, 270-277.

Goldberg, M., Fessenden, J. M. \& RACKer, E. (1966). Phosphoketolase. Methods of Enzymology 9, 515-520.

Henrick, K., Blow, D. M., Carrell, H. L. \& Glusker, J. P. (1987). Camparison of backbone structures of glucose isomerase from Streptomyces and Arthrobacter. Protein Engineering 1, 467-469.

JEFFRIES, T. W. (1983). Utilization of xylose by bacteria, yeasts and fungi. Advances in Biochemical Engineering - Biotechnology 27, 1-32.

Kasumi, T., Hayashi, K. \& Tsumura, N. (1981). Subunit structure of glucose isomerase from Streptomyces griseofuscus S-41. Agricultural and Biological Chemistry 45, 1095-1103.

Kersters-Hilderson, H., Claeyssens, M., van Dorrslaer, E., Saman, E. \& De BruYne, C. (1982). $\beta$-D-Xylosidase from Bacillus pumilus. Methods in Enzymology 83, 631-639.

LAEMMLI, U. K. (1970). Cleavage of structural proteins during the assembly of the head of bacteriophage T4. Nature, London 227, 680685.

Lam, V. M. S., Daruwalla, K. R., Henderson, P. J. F. \& JonesMORTIMER, M. C. (1980). Protein-linked D-xylose transport in Escherichia coli. Journal of Bacteriology 143, 396-402. 
lawlis, B. V., Dennis, M. S., Chen, E. Y., Smith, D. H. \& Henner, D. J. (1984). Cloning and sequencing of the xylose isomerase and xylulose kinase genes of Escherichia coli. Applied and Environmental Microbiology 47, 15-21.

LeVene, P. A. \& RaYmond, A. L. (1933). Phosphoric esters of xylose and of 5-methyl monoacetone xylose. Their bearing on the nature of the pentose of yeast nucleic acid. Journal of Biological Chemistry 102, 347-355.

Marcel, T., Dorcourt, D. \& Tiraby, G. (1987). Cloning of the glucose isomerase (D-xylose isomerase) and xylulose kinase genes of Streptomyces violaceoniger. Molecular and General Genetics 208, 121126.

MARTIN, R. G. \& AMEs, B. N. (1961). A method for determining the sedimentation behavior of enzymes: application to protein mixtures. Journal of Biological Chemistry 236, 1372-1379.

MOORE, S. \& LINK, K. P. (1940). Carbohydrate characterization. Journal of Biological Chemistry 133, 293-311.

NoltmanN, E. A. (1972). Aldose-ketose isomerases acting on nonphosphorylated sugars. In The Enzymes, 3rd edn, vol. 6, pp. 340354. Edited by P. D. Boyer. New York: Academic Press.

Panbangred, W., Shinmyo, A., Kinoshita, S. \& OkadA, H. (1983a). Purification and properties of endoxylanase produced by Bacillus pumilus. Agricultural and Biological Chemistry 47, 957-963.

Panbangred, W., Kondo, T., Negoro, S., Shinmyo, A. \& OKada, H. $(1983 b)$. Molecular cloning of the genes for xylan degradation of Bacillus pumilus and their expression in Escherichia coli. Molecular and General Genetics 192, 335-341.

RAINES, R. \& KNOWLES, J. R. (1986). The mechanistic pathway of a mutant triosephosphate isomerase. Annals of the New York Academy of Sciences 471, 266-271.

ReHM, H.-J. \& REED, G. (1982). Ethanol from pentoses. In Biotechnology, vol. 3, pp. 318-323. Edited by H.-J. Rehm \& G. Reed. Weinheim: Verlag Chemie.

SCHER, B. M. \& HoRECKeR, B. L. (1966). Polyol-dehydrogenases of Candida utilis. Methods in Enzymology 9, 166-170.

SCHMinCKe-OTT, E. \& BisswaNGER, H. (1980). A simple and gentle method for concentrating protein solutions. Preparative Biochemistry 10, 69-75.

Shamanna, D. K. \& SANDERSON, K. E. (1979). Genetics and regulation of D-xylose utilization in Salmonella typhimurium LT2. Journal of Bacteriology 139, 71-79.
SOMOGYI, M. (1952). Notes on sugar determination. Journal of Biological Chemistry 195, 19-23.

Sonnleitner, B., Cometta, S. \& Fiechter, A. (1982). Equipment and growth inhibition of thermophilic bacteria. Biotechnology and Bioengineering 24, 2597-2599.

Straus, D., Raines, R., Kawashima, E., Knowles, J. R. \& Gilbert, W. (1985). Active site of triose-phosphate isomerase: in vitro mutagenesis and characterization of an altered enzyme. Proceedings of the National Academy of Sciences of the United States of America 82 , 2272-2276.

Suekane, M., Tamura, M. \& Tomimura, C. (1978). Physicochemical and enzymatic properties of purified glucose isomerase from Streptomyces olivochromogenes and Bacillus stearothermophilus. Agricultural and Biological Chemistry 42, 909-917.

Sundberg, L. \& PoRath, J. (1974). Preparation of a adsorbents for biospecific affinity chromatography. Journal of Chromatography 90 , 87-98.

Vangrysperre, W., Callens, M., Kersters-Hilderson, H. \& De BRUYNE, C. K. (1988). Evidence for an essential histidine residue in D-xylose isomerases. Biochemical Journal 250, 153-160.

Vangrysperre, W., Kersters-Hilderson, H., Callens, M. \& De BRUYNE, C. K. (1989). Reaction of Woodward's reagent K with Dxylose isomerases. Biochemical Journal 260, 163-169.

WILHELM, M. \& HollenBERG, C. P. (1985). Nucleotide sequence of the Bacillus subtilis xylose isomerase gene: extensive homology between the Bacillus and the Escherichia coli enzyme. Nucleic Acids Research 13, 5717-5722.

Yamanaka, K. \& Takahara, N. (1977). Purification of the D-xylose isomerase from Lactobacillus xylosus. Agricultural and Biological Chemistry 41, 1909-1915.

Yoshida, T., LORENCE, R. M., CHOC, M. G., TARR, G. E., Findling, K. L. \& FEE, J. A. (1984). Respiratory proteins from the extremely thermophilic aerobic bacterium Thermus thermophilus. Journal of Biological Chemistry 259, 112-125.

Young, J. M., Schray, K. J. \& Mildvan, A. S. (1975). Proton magnetic resonance relaxation studies of the interaction of D-xylose and xylitol with D-xylose isomerase. Characterization of metalenzyme-substrate interactions. Journal of Biological Chemistry 250, 9021-9027. 